\title{
A Review of Carbon Footprint Reduction in Construction Industry, from Design to Operation
}

\author{
Banu Sizirici $^{1}$, Yohanna Fseha ${ }^{1}\left(\mathbb{D}\right.$, Chung-Suk Cho ${ }^{1, *}$, Ibrahim Yildiz $^{2}$ and Young-Ji Byon ${ }^{1}(\mathbb{C}$ \\ 1 Department of Civil Infrastructure and Environmental Engineering, Khalifa University, \\ Abu Dhabi P.O. Box 127788, United Arab Emirates; banu.yildiz@ku.ac.ae (B.S.); 100049403@ku.ac.ae (Y.F.); \\ youngji.byon@ku.ac.ae (Y.-J.B.) \\ 2 Department of Chemistry, Khalifa University, Abu Dhabi P.O. Box 127788, United Arab Emirates; \\ ibrahim.yildiz@ku.ac.ae \\ * Correspondence: chung.cho@ku.ac.ae
}

Citation: Sizirici, B.; Fseha, Y.; Cho, C.-S.; Yildiz, I.; Byon, Y.-J. A Review of Carbon Footprint Reduction in Construction Industry, from Design to Operation. Materials 2021, 14, 6094 https://doi.org/10.3390/ma14206094

Academic Editor: Alessandro

P. Fantilli

Received: 9 September 2021

Accepted: 12 October 2021

Published: 15 October 2021

Publisher's Note: MDPI stays neutral with regard to jurisdictional claims in published maps and institutional affiliations.

Copyright: (c) 2021 by the authors. Licensee MDPI, Basel, Switzerland This article is an open access article distributed under the terms and conditions of the Creative Commons Attribution (CC BY) license (https:// creativecommons.org/licenses/by/ $4.0 /)$

\begin{abstract}
Construction is among the leading industries/activities contributing the largest carbon footprint. This review paper aims to promote awareness of the sources of carbon footprint in the construction industry, from design to operation and management during manufacturing, transportation, construction, operations, maintenance and management, and end-of-life deconstruction phases. In addition, it summarizes the latest studies on carbon footprint reduction strategies in different phases of construction by the use of alternative additives in building materials, improvements in design, recycling construction waste, promoting the utility of alternative water resources, and increasing efficiencies of water technologies and other building systems. It was reported that the application of alternative additives/materials or techniques/systems can reduce up to $90 \%$ of $\mathrm{CO}_{2}$ emissions at different stages in the construction and building operations. Therefore, this review can be beneficial at the stage of conceptualization, design, and construction to assist clients and stakeholders in selecting materials and systems; consequently, it promotes consciousness of the environmental impacts of fabrication, transportation, and operation.
\end{abstract}

Keywords: embodied carbon; recycled asphalt; recycled aggregate; construction waste materials; alternative additives; alternative water resources

\section{Introduction}

This paper aims to bring attention to the carbon footprint in the construction industry (building, maintaining, and deconstructing the structures), since the construction industry is listed as the single largest global consumer of resources [1,2]. In the European Union, building construction consumes $40 \%$ of materials and $40 \%$ of primary energy, and generates $40 \%$ of waste annually [1]. Globally, in developed and developing countries, buildings contributes to $33 \%$ of the greenhouse gas (GHG) emissions and $40 \%$ of the global energy consumption which stem from the usage of the equipment, the manufacturing of building materials and transportation $[3,4]$. The total $\mathrm{CO}_{2}$ emission of the construction sector was 5.7 billion tons which made up 23\% of the emissions of global economic activity in 2009 [5]. Globally, the urban population is predicted to exceed six billion in 2045, and this could lead to more construction in the future.

According to the 4th Assessment Report of the Intergovernmental Panel on Climate Change (IPCC), GHG emissions from buildings contributed 8.6 billion t-CO $\mathrm{CO}_{2}$-e in 2004 . It is predicted that it could reach up to 15.6 billion $\mathrm{t}-\mathrm{CO}_{2}$-e by 2030 , creating an increase of $26 \% \mathrm{CO}_{2}$ which accounts for $30-40 \%$ of the total GHG emissions [6]. It is necessary to take action to reduce GHGs resulted from construction activities. Hence, it is vital to implement policies that focus on GHG emissions mitigation. Such schemes are broadly classified into two approaches: (1) indirect pricing such as regulations and (2) direct pricing such as carbon taxes and emission trading schemes (ETS) [7]. 
Regulations such as building codes can effectively reduce GHG emissions if enforced well enough, and can ensure new buildings incorporate designs that are both cost and energy effective [8]. Required codes, including the European Union's zero energy mandate by 2021, Australia's NatHERS 5-star standard, volunteer certificates such as Leadership in Energy and Environmental Design (LEED) which is required for all new federal government construction projects and renovations in the USA but voluntary for private construction, and the Building Research Establishment Environmental Assessment Method (BREEAM), would force designers and contractors to reconsider material usage that has a high embodied carbon content and also to rethink way they conduct their operations $[9,10]$.

Another instrument for the mitigation of GHG emission is the carbon tax. Carbon taxes are simpler to design, have relatively low administration costs, and are attractive to stakeholders in the building sector due to their familiarity with the tax mechanism [11,12]. Carbon taxes encourage industry and the general public to help reduce GHG emissions by using energy efficiently and opting for cleaner, renewable sources of energy which in turn leads to innovations in technology and processes [13]. In terms of ETS, the cumulative amount of GHG emissions mitigated can be quantified with ETS and emission permits can be distributed for free or auctioned off $[7,14]$. As both energy supply and demand have equal weights, an ETS can be especially useful in the construction industry, thereby, encouraging the use of technologies that are energy efficient [15].

Studies have shown that a variety of factors slow down the move towards a carbon neutral construction industry. A study conducted in Singapore and Hong Kong found that lack of awareness, education, incentives, and high initial costs are the obstacles to such a move [16]. In another study that focused on commercial buildings in the Chinese cities of Beijing and Shanghai, the barriers were identified to be lack of regulations and financial incentives, ineffective monitoring, and lack of awareness around energy saving [17]. Therefore, this paper aims to bring attention/awareness where carbon footprint resulting from design to operation/management phases, such as manufacturing, transportation, construction, operation and maintenance, and end-of-life deconstruction in construction industry. If these sources are well identified, it will be helpful to reduce GHGs at the stage of conceptualization, design, construction, and management via selecting material, system, operation and management having less carbon footprint, which will promote environmental consciousness in whole construction operations.

There are many studies focused on $\mathrm{CO}_{2}$ reduction at different phases in the construction industry. However, there is no other study focusing on carbon reduction in all stages from design to operation and management phases with emphasis on manufacturing, transportation, construction, operation and maintenance, and end-of-life deconstruction comprehensively. Therefore, this paper reviewed a variety of the latest techniques for reducing the carbon footprint of each phase such as the use of alternative additives in building materials, improvements in the design, recycling of construction waste, promoting the use of alternative water resources, increasing the efficiency of water technologies, and building novel systems to improve the sustainability of the construction industry.

\section{Carbon Footprint of Mining, Manufacturing, and Materials Transporting in the Construction Industry and GHG Reduction}

Construction process undergoes several phases, starting with production of materials (non-metallic minerals, oil, cement mortar, iron, steel, concrete) and material transportation which contributes $82-96 \%$ of the total $\mathrm{CO}_{2}$ emissions through the construction period as shown in Figure 1 [18-21]. 


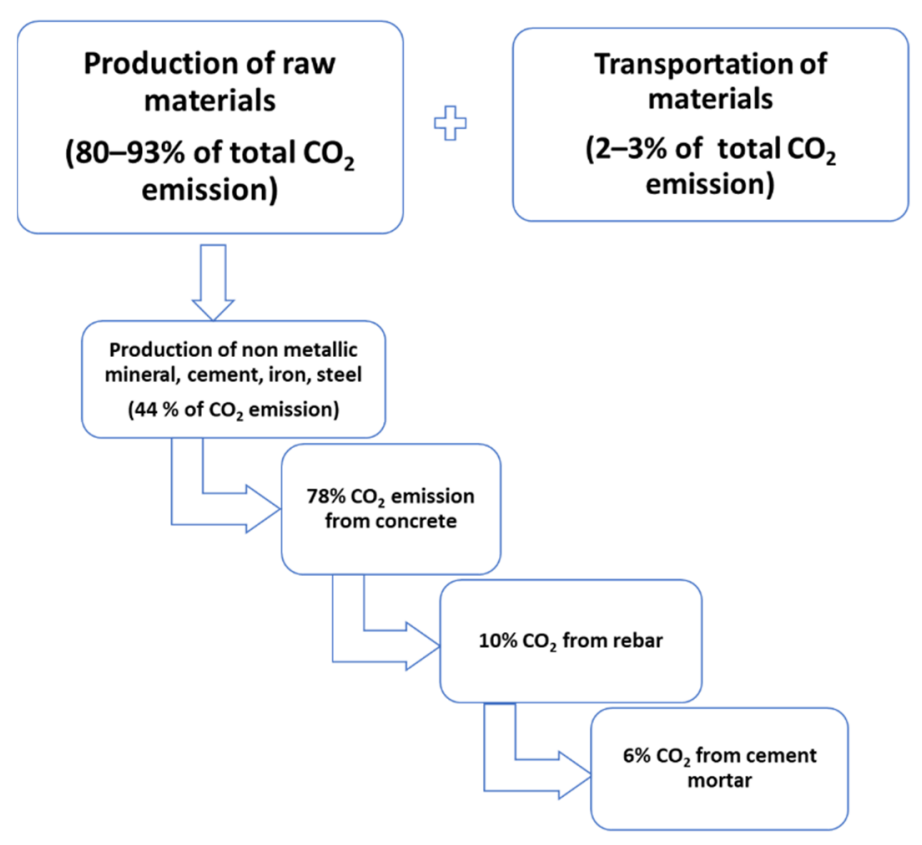

Figure 1. $\mathrm{CO}_{2}$ emission from different phases in the construction industry.

A study showed that carbon footprint of urban buildings increased from 8.95 million tons in 2005 to 13.57 million tons in 2009 , and that $45 \%$ of $\mathrm{CO}_{2}$ resulted from building material production whereas $40 \%$ of $\mathrm{CO}_{2}$ resulted from building energy in Xiamen, China [22]. Another study indicated that life-cycle carbon emission of a five-story brick-concrete residential building in Nanjing city of PR China was $1807.31 \mathrm{t}$, and $90 \%$ of $\mathrm{CO}_{2}$ were emitted at the stage of construction materials preparation and the stage of building operation [23].

\subsection{Carbon Footprint of Limestone Quarrying}

Limestone is one of the largest produced crushed rocks which is the basic component of construction materials, such as aggregate, lime, cement, and building stones for the construction industry [24]. The energy required for lime quarrying is associated with the machine fuel, diesel, and electricity that are needed for the limestone processing. The machines used together with their energy requirements and $\mathrm{CO}_{2}$ emissions are listed in Figure 2. A study found that the main cause of resource depletion in limestone quarrying was the use of diesel fuel in the transportation process, and that based on the GHG Protocol the GHGs emission was found to be $3.13 \mathrm{~kg} \mathrm{CO}$ eq. per ton crushed rock product. This study suggested the adoption of alternative renewable energies such as solar, thermal, and biodiesel which will have significant impact on the reduction of GHG emissions (0.21 Mt-CO 2 eq. annually) [25]. 


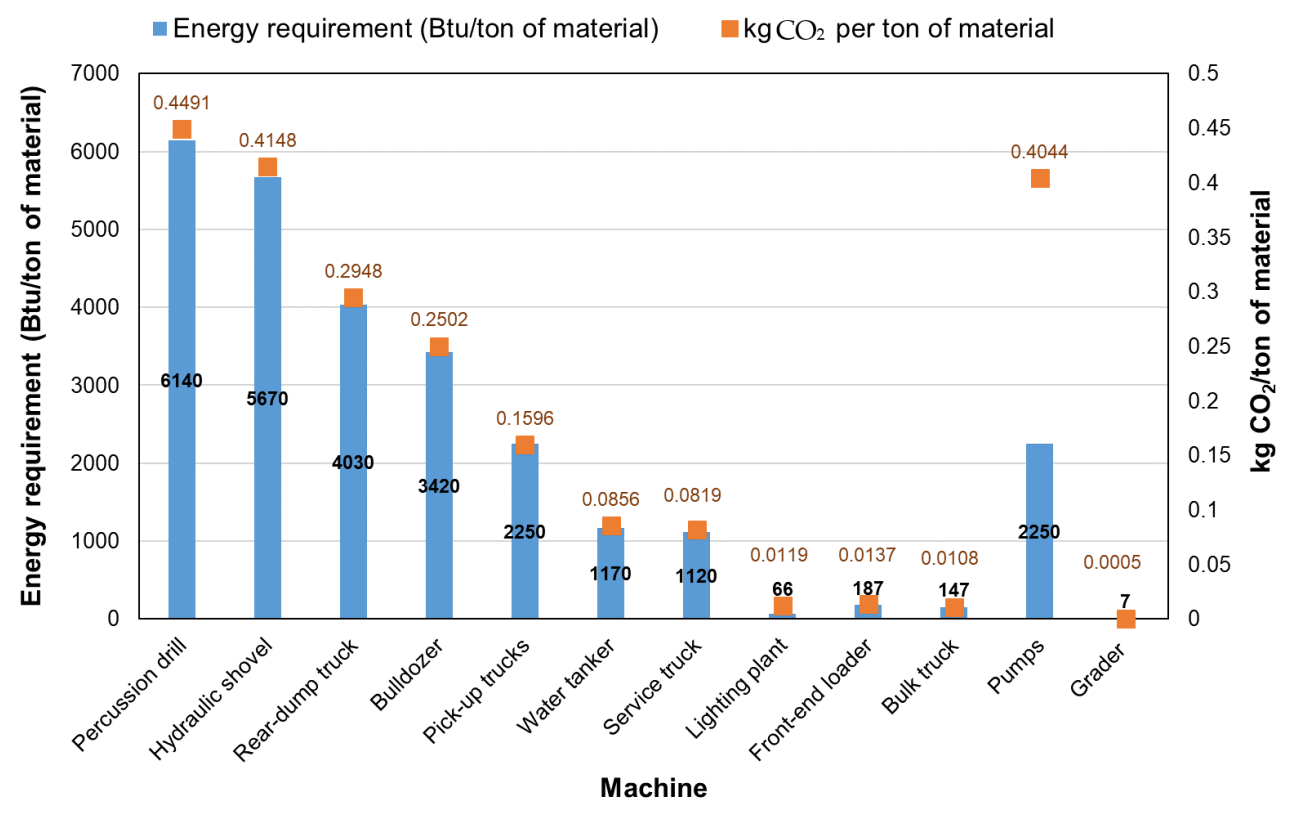

Figure 2. The machines used together with their energy requirements and $\mathrm{CO}_{2}$ emissions in limestone processing. Adapted from [24].

\subsection{Carbon Footprint of Cement and Concrete Manufacturing}

Globally, cement manufacturing accounts for $5 \%$ of $\mathrm{CO}_{2}$ emissions [26]. It has been reported that manufacturing of $1 \mathrm{~kg}$ of Portland clinker releases nearly $1 \mathrm{~kg}$ of $\mathrm{CO}_{2}$ to the atmosphere. The calcination process that takes place in the cement kiln contributes nearly $0.55 \mathrm{~kg} \mathrm{CO}$ per $\mathrm{kg}$ of cement clinker [27]. Concrete's typical composition is $34 \%$ sand, $12 \%$ Portland cement, $48 \%$ crushed stone, and $6 \%$ water. Since the cement percentage is relatively small in concrete, it is considered non-energy intensive compared to other construction materials [24]. $\mathrm{CO}_{2}$ emission rate during the production of concrete is between 347 and $351 \mathrm{~kg}$ of $\mathrm{CO}_{2}-\mathrm{e} / \mathrm{m}^{3}$ [28]. According to Solís-Guzmán, Cement II/AL $32.5 \mathrm{~N}$ in two four-story blocks of flats (a total of 107 dwellings with total area of 10,243.69 $\mathrm{m}^{2}$ ) gives 148,180 $\mathrm{kg} \mathrm{CO}_{2}$ eq/year and concrete $\mathrm{HA} 25 / \mathrm{B} / 40$ gives $312,596.55 \mathrm{~kg} \mathrm{CO}_{2}$ eq/year during one year of construction process [1]. A study in China reported that $1 \mathrm{~km}$ Portland cement concrete pavement construction gives $8215.31 \mathrm{CO}_{2} \mathrm{e}$ tons in which raw material production accounts for $92.7 \%$, concrete manufacturing phase accounts for $7.2 \%$ and onsite pavement construction phase accounts for $0.1 \%$ of the total GHG emissions [26]. The energy consumption on-site and $\mathrm{CO}_{2}$ emissions from the production of cement/concrete annually are listed in Table 1 . The United States was the third largest producer of cement globally with 50-55 million metric tons (Mt) of $\mathrm{CO}_{2}$ eq emissions which is equivalent to $4 \%$ of the total GHG emissions in the country in 2012. These numbers are expected to increase further as the production of cement grows [29].

Table 1. On-site energy consumption and $\mathrm{CO}_{2}$ emissions from cement/concrete production annually. Adapted from [24,26].

\begin{tabular}{|c|c|c|c|c|c|}
\hline \multirow{2}{*}{\multicolumn{2}{|c|}{ Activity }} & \multicolumn{2}{|c|}{ Cement } & \multicolumn{2}{|c|}{ Concrete } \\
\hline & & Energy Use/Ton (Btu) & $\begin{array}{l}\mathrm{CO}_{2} \text { Emissions } \\
\text { (Ton)/Ton of Material }\end{array}$ & Energy Use/Ton (Btu) & $\begin{array}{l}\mathrm{CO}_{2} \text { Emissions } \\
\text { (Ton)/Ton of Material }\end{array}$ \\
\hline \multicolumn{2}{|c|}{ Quarrying and crushing } & $4.29 \times 10^{4}$ & $4.05 \times 10^{-3}$ & $1.61 \times 10^{5}$ & $1.44 \times 10^{-2}$ \\
\hline \multirow{4}{*}{$\begin{array}{c}\text { Cement } \\
\text { manufacturing }\end{array}$} & Raw grinding & $9.39 \times 10^{4}$ & $1.69 \times 10^{-2}$ & & \\
\hline & Kiln fuels & $4.62 \times 10^{6}$ & $4.33 \times 10^{-1}$ & & \\
\hline & Reactions & & $5.44 \times 10^{-1}$ & & \\
\hline & Finish milling & $2.71 \times 10^{5}$ & $4.86 \times 10^{-2}$ & & \\
\hline \multirow{2}{*}{$\begin{array}{l}\text { Concrete } \\
\text { production }\end{array}$} & Blending/mixing & & & $3.54 \times 10^{5}$ & $6.36 \times 10^{-2}$ \\
\hline & Transportation & & & $6.97 \times 10^{5}$ & $5.10 \times 10^{-2}$ \\
\hline
\end{tabular}




\subsection{Carbon Footprint of Asphalt Production and Construction}

Asphalt is a substance used as binder for pavement materials. The energy consumption for asphalt binder production includes the extraction of crude oil, transportation, and the refining process. The energy consumption for asphalt binders is $4900 \mathrm{MJ}$ per ton, and the corresponding GHG emissions is $285 \mathrm{~kg} \mathrm{CO}_{2}$ per ton [30]. Heating aggregates account for $67 \% \mathrm{CO}_{2}$ emission, asphalt heating accounts for $14 \% \mathrm{CO}_{2}$, and mixing process accounts for $12 \%$ of total carbon emissions [31]. A case study in China reported that $20 \mathrm{~km}$ long asphalt pavement construction emitted 52,264,916.06 $\mathrm{kg} \mathrm{CO}_{2}$-e, which includes raw materials production accounting for $43 \%$ of total GHG emissions, mixing accounting for $54 \%$ of total GHG emissions, and transportation, laying, compacting, and curing phase accounting for $3 \%$ of total GHG emission [32].

\subsection{Carbon Footprint of Steel Production}

Steel production starts with the reaction between iron ore and a reducing agent, coking coal, in the blast furnaces producing melted iron which is converted to steel in a later stage. The reaction of iron ore with carbon is the major contributor of $\mathrm{CO}_{2}$ emission in the steel production corresponding to $70-80 \%$ of the total $\mathrm{CO}_{2}$ emissions [25]. Globally, steel manufacturing accounts for $6 \%$ of $\mathrm{CO}_{2}$ emissions [33]. Globally, steel manufacturing accounts for $6 \%$ of $\mathrm{CO}_{2}$ emissions [26]. According to Solis Guzmán [1], Steel B $500 \mathrm{~S}$ in two four-story blocks of flats (a total of 107 dwellings with total area of $10,243.69 \mathrm{~m}^{2}$ ) gives $281,898.38 \mathrm{~kg} \mathrm{CO}_{2}$ eq/year during one year of construction process. Table 2 shows the energy type and consumption, and $\mathrm{CO}_{2}$ emissions associated with steel production in the integrated steel making and secondary steel making stages.

Table 2. The energy type and consumption and the $\mathrm{CO}_{2}$ emissions associated with steel production. Adapted from [34].

\begin{tabular}{|c|c|c|c|}
\hline Activity & Energy Type and Consumption & Final Energy (MBtu/Ton) & $\mathrm{CO}_{2}$ Emission (Ton)/Ton of Material \\
\hline \multicolumn{4}{|c|}{ Primary steel making } \\
\hline Sinter making & 26 PJ fuel and 2 PJ electricity & 0.264 & 0.009 \\
\hline Coke making & $74 \mathrm{PJ}$ fuel and $2 \mathrm{PJ}$ electricity & 0.718 & 0.007 \\
\hline Iron making & $676 \mathrm{PJ}$ fuel and $4 \mathrm{PJ}$ electricity & 6.421 & 0.120 \\
\hline Steel making (Basic oxygen furnace) & 19 PJ fuel and 6 PJ electricity & 0.236 & 0.005 \\
\hline Casting & 15 PJ fuel and 11 PJ electricity & 0.236 & 0.010 \\
\hline Hot rolling & 157 PJ fuel and 34 PJ electricity & 1.803 & 0.041 \\
\hline Cold rolling and finishing & 43 PJ fuel and 15 PJ electricity & 0.548 & 0.014 \\
\hline Boilers & $167 \mathrm{PJ}$ fuel and 0 electricity & 1.577 & 0.085 \\
\hline Co-generation (integrated steel making) & $101 \mathrm{PJ}$ fuel and -22 PJ electricity & 0.746 & 0.004 \\
\hline \multicolumn{4}{|c|}{ Secondary steel making } \\
\hline Steel making using electric arc furnace & 6 PJ fuel and 62 PJ electricity & 0.642 & 0.031 \\
\hline Casting & $1 \mathrm{PJ}$ fuel and 4 PJ electricity & 0.028 & 0.002 \\
\hline Hot rolling & 102 PJ fuel and 22 PJ electricity & 1.171 & 0.026 \\
\hline Cold rolling and finishing & Not required & none & - \\
\hline Boilers & $42 \mathrm{PJ}$ fuel and $0 \mathrm{PJ}$ electricity & 0.397 & 0.026 \\
\hline Co-generation & 11 PJ fuel and -2 PJ electricity & 0.085 & 0.0004 \\
\hline
\end{tabular}

\subsection{GHG Reduction in Materials and Chemicals}

Alternative additives or recycled concrete waste materials can be used in common construction materials such as cement, concrete, asphalt, and clay to reduce environmental impact in the construction industry.

\subsubsection{Cement and Concrete Additives}

Cement manufacturing requires energy; therefore, it is recommended to substitute the clinker content partially with industrial by-products. It is safe to substitute the clinker content by $30 \%$ (by weight of total binder) without compromising the strength or performance [35-38]. Also, high energy milling can be done to blend constituents to increase their reactivity and to increase their surface area, both of which can help improve the compres- 
sive strength development [39]. Recent studies have shown that regular Portland Cement can be replaced with alkali-activated slag mortars. These alkali-activated slags (AAS) can help reduce environmental impacts greatly since the production of AAS results in low energy consumption and lower energy consumption leading to lower $\mathrm{CO}_{2}$ emissions [40].

The admixtures used for alkali-activated slag were Peramin SRA 40 (SRA), polymer polyethylene glycol (PEG), and polypropylene glycol (PPG) [41]. In order to reduce the $\mathrm{CO}_{2}$ emissions, alternative clinker chemistries can be used as well as changing cement production methods in favor of more energy efficient technologies which result in reduction of $374 \mathrm{~kg} \mathrm{CO} / \mathrm{t}$ clinker and totaling annual 224,540 $\mathrm{t}-\mathrm{CO}_{2}$ emission release [42]. Table 3 reports $\mathrm{CO}_{2}$ emission reductions from some alternative technologies and materials in cement manufacturing. For instance, fluidized bed kilns can be used instead of conventional rotary kilns to burn raw materials into powder using a new technology called granulation control/hot self-granulation; such a change can lower energy consumption by $10-15 \%$ and reduce $\mathrm{NO}_{\mathrm{x}}$ emissions to $0.77 \mathrm{~kg}$ per ton of clinker as compared to $2.1-2.6 \mathrm{~kg}$ per ton of clinker for conventional kilns [43]. Oxy-fuel technologies have emerged as a promising candidate for $\mathrm{CO}_{2}$ capture in new cement kilns by using pure oxygen for fuel burning. Due to reduced fuel combustion, oxy-fuel technology reduces $\mathrm{CO}_{2}$ emissions by $454-726 \mathrm{~kg}$ $\mathrm{CO}_{2}$ per ton of cement. However, due to increased electricity usage, $\mathrm{CO}_{2}$ emissions increase slightly by $50-68 \mathrm{~kg}$ of $\mathrm{CO}_{2}$ per ton of cement [44].

Table 3. Reduction in $\mathrm{CO}_{2}$ emissions from alternative technology/materials in cement production. Adapted from [42].

\begin{tabular}{|c|c|c|}
\hline Technology/Material & Alternative & Reduction in $\mathrm{CO}_{2}$ Emissions \\
\hline Cement production methods & Fluidized bed kiln; high activation grinding & 20 to $30 \mathrm{~kg} \mathrm{CO} /$ ton product \\
\hline & Calcareous oil shale, steel slag & $60 \mathrm{~kg} \mathrm{CO} /$ ton of clinker \\
\hline Changes in raw material & Carbide slag & $374 \mathrm{~kg} \mathrm{CO} /$ ton of clinker \\
\hline \multirow{3}{*}{ Emerging alternative cement products } & Novacem cement & $750 \mathrm{~kg} \mathrm{CO} /$ ton product \\
\hline & Geopolymer cement & $300 \mathrm{~kg} \mathrm{CO}_{2} /$ ton product \\
\hline & Calera cement manufacturing & $500 \mathrm{~kg} \mathrm{CO} /$ ton of product \\
\hline \multirow[t]{2}{*}{ Carbon capture technologies } & Concrete curing & $120 \mathrm{~kg} \mathrm{CO}_{2} /$ ton product \\
\hline & Carbonate looping & 370 to $500 \mathrm{~kg} \mathrm{CO}_{2} /$ ton product \\
\hline Fuel technologies & Oxygen enrichment and Oxy-fuel & 404 to $676 \mathrm{~kg} \mathrm{CO}_{2} /$ ton cement \\
\hline Post-combustion carbon capture & Absorption & 690 to $725 \mathrm{CO}_{2} /$ ton clinker \\
\hline Industrial recycling & $\begin{array}{l}\mathrm{CO}_{2} \text { from cement process into high-energy } \\
\text { algal biomass }\end{array}$ & $\begin{array}{c}1800 \mathrm{~kg} \text { of } \mathrm{CO}_{2} \text { will be utilized per ton of } \\
\text { dry algal biomass produced }\end{array}$ \\
\hline
\end{tabular}

In order to mitigate the impact of concrete on the environment, its physical and mechanical properties such as strength, durability and light weight can be enhanced. For instance, lightweight concretes (LWCs) with high volume of additives such as fly ash or silica fume, which reduces the overall structural volume to withstand load, reduces $\mathrm{CO}_{2}$ emissions by $30-50 \%$ as compared to conventional concrete and improves mechanical properties of LWC [45]. Demolition waste such as old tires, crushed glass, and various materials from the incineration process can be granulated and cast into concrete as fillers [27]. According to a study, a sustainable Ultra High-Performance Fiber Reinforced Cement Composite (UHPFRCC) was produced using silica flour, blast-furnace slag cement, silica fume, superplasticizers, wollastonite, and steel fibers [46].

Another study stated that pulverized fuel ash (PFA) and high calcium wood ash (HCWA) were reused as concrete materials and HCWA:PFA of 50:50 and 40:60 provide the optimal flexural and compressive strength [47]. Titanium dioxide $\left(\mathrm{TiO}_{2}\right)$ can be used as both an additive and as a coating layer. It was found that photocatalytic concrete containing $\mathrm{TiO}_{2}$ was effective to remove $\mathrm{NO}_{\mathrm{x}}$ in urban streets [48]. According to a study, the carbon footprint of a building with $4020 \mathrm{~m}^{2}$ gross area and 5633 tons of total weight was 14,229 tons of $\mathrm{CO}_{2}-\mathrm{e}$; in particular, this building contributed to $42 \%$ of the total emissions during both productions of material and construction stages [49]. A fractional replacement of cement in concrete with fly-ash together with the use of ground granulated blast furnace slag and the use of natural aggregates with recycle crushed aggregate can reduce up to $3.8 \%$ (10.5 kg 
$\left.\mathrm{CO}_{2}-\mathrm{e}\right)$ in comparison to the conventional concrete mixture during the life cycle of the building [50].

\subsubsection{Asphalt Additives}

Asphalt is used in most road and pavement construction, and it is a considerable contributor to GHGs in construction industry [31]. There are several additives that can assist in reducing GHG emissions, such as Sasobit, which also can reduce mixture viscosity and lower conventional mix temperature. Recent studies compared Warm Mix Asphalt (WMA) and Hot Mix Asphalt (HMA) in terms of their emission profiles. It was determined that mixture containing Sasobit additives with WMA produces the lowest $\mathrm{CO}_{2}$ emissions which ranges from $450 \mathrm{ppm}$ to $550 \mathrm{ppm}$ while HMA produces $700 \mathrm{ppm}$ to $750 \mathrm{ppm}$ of $\mathrm{CO}_{2}$ [41]. Another additive for the production of WMA is synthetic zeolite. It reduces the viscosity and increases asphalt mixtures' workability. Furthermore, by allowing stronger coatings of bitumen on aggregates, it improves the bonding [51]. To improve the bonding of aggregates with bitumen at low temperature, zeolite can be doped with $\mathrm{Ca}(\mathrm{OH})_{2}$ which would also control the emission of $\mathrm{CO}_{2}$ [52]. Studies have shown that with the addition of $6 \%$ of additive by weight, mixing temperatures of asphalt mixtures reduced from $180^{\circ} \mathrm{C} \mathrm{HMA}$ to $120^{\circ} \mathrm{C}$ WMA which in turn reduces the $\mathrm{CO}_{2}$ emissions from $7500 \mathrm{ppm}$ to $500 \mathrm{ppm}[53]$.

\subsubsection{Clay Additives}

Fired and unfired clay bricks are used in the construction industry. However, fired clay bricks require a large amount of energy for their production [54]. In order to lessen the environmental impacts and achieve sustainable building industry development, unfired clay bricks are more suitable than fired bricks. Unfired clay bricks are composed of clay soils and a binder such as lime or cement [55]. Calcium-based binder such as lime and cement increases carbon in the air, due to high energy consumption during manufacturing; furthermore, the rocks naturally change $\mathrm{CaCO}_{3}$ into $\mathrm{CaO}$ which further releases $\mathrm{CO}_{2}$ [56]. Various additives have been tested, and it was found that $\mathrm{MgO}$ can be a potential alternative to calcium-based binders. $\mathrm{MgO}$ has some similar attributes of $\mathrm{CaO}$, however $\mathrm{MgO}$ has the ability to immobilize heavy metals in contaminated soil. In addition, magnesite is used in manufacturing refractory products [57]. The reduction of $\mathrm{CO}_{2}$ emissions for unfired clay bricks were estimated $9.96 \mathrm{~kg} \mathrm{CO}_{2}$-e per fu (functional unit) [50].

\subsubsection{Recycled Aggregate Concrete}

In addition to crushed concrete, recycled aggregate concrete (RAC) consists of materials such as bricks, metals, tiles, and other materials including plastic, wood, glass, and paper [4]. RAC has inferior durability and mechanical properties as compared to conventional concrete. However, desirable RAC properties can be obtained by using admixtures such as silica fume, GGBS, fly ash, and meta-kaolin, and by modifying mixing procedures [4]. In a study, it was found that RAC together with industrial wastes such as fly ash, silica fume, blast slag, etc. can improve concrete's carbon footprint and provide great benefits [58]. Chetumal Institute of Technology in Mexico studied the influence of the fine and normal/recycled coarse aggregates on carbon footprint [59]. The result showed that recycled coarse aggregates contributes $39 \%$ of $\mathrm{CO}_{2}-\mathrm{e}$, fine aggregate contributes $19 \%$ of $\mathrm{CO}_{2}$-e and normal coarse aggregate contributes $42 \%$ of $\mathrm{CO}_{2}$-e. The study concluded that increasing recycled aggregates may help reduce 22,343 tons of $\mathrm{CO}_{2}$-e annually in the region of Mexico alone. A study found that $100 \%$ reclaimed and recycled aggregates, which is called Pixelcrete, reduced the content of Portland cement (60\% less than the conventional concrete) in office building, and led to $73.8 \mathrm{t}-\mathrm{CO}_{2}$-e reduction in GHG emission [60].

\subsubsection{Recycled Asphalt}

Reclaimed asphalt pavement (RAP) is used to describe re-used asphalt containing pavement. In 2010, 62.1 million tons of RAP was used in asphalt pavements [61]. The 
RAP could be used in three different categories of production: either as hot mix asphalt, or cold mix asphalt, or as aggregates. The RAP is generated through removal of asphalt pavement by either milling the surface using a milling machine or full depth removal. The recycling process includes both hot and cold mix asphalt and can be done in recycling plant or in place [62]. In a study, it was found that virgin asphalt produces $132 \mathrm{~kg} \mathrm{CO}_{2}$-e per t. In addition, $1 / 3$ of this value was contributed by the energy intensive processes such as heating and drying; therefore, several studies were carried out to determine the factors that affect the reduction of $\mathrm{CO}_{2}$ emissions including the RAP [28]. It was reported that RAP mix resulted in $5.5 \%$ reduction of carbon content, and it enhanced the reduction by $14 \%$ when larger aggregates sizes were used. By using RAP, embodied carbon content dropped to an average of $84.35 \mathrm{~kg} \mathrm{CO}_{2}$-e per $\mathrm{t}$ [3].

\section{Carbon Footprint of On-Site Construction Processes and GHGs Reduction}

Carbon footprints are resulted during manufacturing, transportation, and installation processes of ground foundation, wood/steel/concrete framed construction at on-site construction activities. The amount of $\mathrm{CO}_{2}$ released from a concrete-steel residential tower in the Tehran Metropolitan City was 13,076,390,236 $\mathrm{kg} \mathrm{CO}_{2}$-e, and the amount of $\mathrm{CO}_{2}$ emissions in $1 \mathrm{~m}^{2}$ of Gross Floor Area (GFA) was $435,879.67 \mathrm{~kg} \mathrm{CO} \mathrm{CO}_{2} / \mathrm{m}^{2}$, of which $83 \%$ was related to the emissions from transportation of materials and $14 \%$ was related to construction wastes and 3\% was related to on-site construction process [20]. A prefabricated wood-frame multi-story building in Quebec City produced a total of embodied carbon emissions of $275 \mathrm{~kg} \mathrm{CO}_{2}$-e, which was $25 \%$ less than traditional buildings built with steel or concrete. The fabrication phase of building material contributed the most $(75 \%)$ to the carbon emissions, while transportation (13\%), construction $(1 \%)$, and waste management $(11 \%)$ contributed $25 \%$ [50].

A study found that the embodied carbon of a 3-bedroom semi-detached house constructed using offsite panelized timber frame was approximately $35 \mathrm{t}-\mathrm{CO}_{2}(82 \%$ of the total embodied carbon is embodied in the materials incorporated in the building, $2 \%$ of the total embodied carbon resulted from transportation of the materials from point of distribution to site and the rest resulted from waste materials exported from the site and energy used onsite), and an equivalent home constructed using traditional masonry construction was $52 \mathrm{t}-\mathrm{CO}_{2}$. Using modern methods in construction resulted in a $34 \%$ reduction in embodied carbon [63]. The overall $\mathrm{CO}_{2}$ emissions from the $1008 \mathrm{~m}$ wastewater pipeline project in China were calculated in tons through the entire construction period; the results were found to be 452.81 tons, 61.32 tons, and 6.59 tons from transportation phase, material manufacturing phase, and installation phase, respectively [64]. The global warming and energy consumption of $1 \mathrm{~m}^{2}$ of hoarding construction using large amounts of steel products and concrete in the construction site resulted in 3 tons of $\mathrm{CO}_{2}$ eq GWP and $39 \mathrm{GJ}$ of non-renewable energy consumption [65]. Another study showed that home building with ready mix concrete results in $40 \%$ less $\mathrm{CO}_{2}$ emissions and less fuel consumption per lot by changing concrete slab size from $3000 \mathrm{ft}^{2}$ to $1500 \mathrm{ft}^{2}$. In addition, choosing the closest ready mix concrete plant saves 46 gallons of diesel and eliminates $1020 \mathrm{lb}$ of $\mathrm{CO}_{2}$ emissions per lot in Greater Phoenix Arizona area [66].

Enhancement of energy efficiency and optimization of construction machines can reduce direct carbon emissions in construction industry [67]. Oil and electricity consumption during the on-site construction contribute to carbon footprint of construction industry. According to this study, the sources of $\mathrm{CO}_{2}$ emission from the on-site construction are as follows: reinforced concrete work produced $44.1 \mathrm{t}-\mathrm{CO}_{2}\left(23.9 \%\right.$ of the total $\mathrm{CO}_{2}$ emissions), earthworks produced $39.1 \mathrm{t}-\mathrm{CO}_{2}\left(21.2 \%\right.$ of the total $\mathrm{CO}_{2}$ emissions), ground heat construction (close loop) produced $31.9 \mathrm{t}-\mathrm{CO}_{2}\left(16.7 \%\right.$ of the total $\mathrm{CO}_{2}$ emissions), foundation work (PHC PILE) produced $26.7 \mathrm{t}-\mathrm{CO}_{2}\left(14.4 \%\right.$ of the total $\mathrm{CO}_{2}$ emissions), and ground heat construction (open loop) produced $16.6 \mathrm{t}-\mathrm{CO}_{2}$ (8.5\% of the total $\mathrm{CO}_{2}$ emissions) of $84.6 \%$ of the total $\mathrm{CO}_{2}$ at the on-site construction phase. Furthermore, electricity consumption of concrete works on-site accounts for $41.9 \%$ of the total electricity used during the construction, 
resulting $14.1 \%(13,279 \mathrm{kWh})$ of the total electricity usage during building operations [21]. A case study has shown that on an average $99.8 \%$ of carbon present in the fossil fuel consumed by an excavator is released into the atmosphere as $\mathrm{CO}_{2}[5,67]$. Additionally, emission factors during idling times contribute to overall average emission factors.

A study showed that the total $\mathrm{CO}_{2}$ emission increased during engine idling of nonroad diesel construction equipment was considered although during the idle the time fuel use and $\mathrm{CO}_{2}$ emissions are between $1 / 3$ to $1 / 5$ of the non-idle time. During idling time, $2.7 \mathrm{~kg} \mathrm{CO}$ / liter was produced at a diesel fuel consumption rate of $03.7 \mathrm{~L} / \mathrm{h}$ [68]. According to the EPA (2005), operators should take the equipment needs into consideration, including the time required for warm-ups and cool-downs. An operational efficiency system that is commonly accepted and used to estimate equipment productivity is $50 \mathrm{~min}=\mathrm{h}(83 \%)$, which indicates $50 \mathrm{~min}$ of non-idle time and $10 \mathrm{~min}$ of idle time per hour. Equipment such as backhoes and bulldozers have equipment productivity ranging from $80 \%$ to $85 \%$. However, off-road trucks have equipment productivity of $41 \%$ considering that a large part of their time is spent cycle idling, mainly loading and offloading of cargo. If off-road truck average operational efficiency increased from $40 \%$ to $50 \%$ by reducing idle time by only $6 \mathrm{~min} / \mathrm{h}$, the hourly fuel use and $\mathrm{CO}_{2}$ emissions can be reduced $10 \%$ [68].

A case study of a construction project in USA involved a roadway construction of an 18.8-mile highway requiring 184 pieces of machinery categorized into 35 equipment types, with idle time assumed to be $6 \mathrm{~h}$ per day for 7 days per week for this machinery. It was shown that the net total emission was $179,055 \mathrm{Mt}-\mathrm{CO}_{2}$-e during a period of 2.5 years (71,609 $\mathrm{Mt}-\mathrm{CO}_{2}$-e per year), of which $40,023 \mathrm{Mt}-\mathrm{CO}_{2}-\mathrm{e} / \mathrm{km}$ was contributed by the constructed roadway [69]. Amount of $\mathrm{CO}_{2}$ resulted from idling time can be reduced using different technologies such as direct-fire heaters, auxiliary power units (APU), thermal storage systems, on-board batteries, and automatic engine shut-off devices [70]. According to a study, direct fired heaters can reduce $\mathrm{NO}_{x}$ and $\mathrm{CO}_{2}$ emissions by $99 \%$ and $94-96 \%$, respectively, since heat is transferred directly to the heat exchanger from the combustion flame resulting in less fuel usage than diesel engines [71].

\section{Carbon Footprint of Construction and Demolition Waste Generation and GHG Reduction}

Construction demolition waste (CDW) stems from construction, renovation, and demolition workplaces which include (i) excavation materials, (ii) road building and maintenance materials, (iii) demolition materials, and (iv) other worksite waste materials, (e.g., unpainted, non-treated wood scrap, unpainted, non-treated wood pallets, plastic, packaging), land clearing, and development activities [72]. Construction waste is increasing in volume and affecting the environment adversely [73]. Over $80 \%$ of CDW is composed of excavated earth in construction works. Mixed CDW contains the remaining of materials and packaging. [74] A 3-bedroom modular timber frame semi-detached house with $83 \mathrm{~m}^{2}$ internal floor area produced $17 \mathrm{~m}^{3}$ of waste (excavated inert materials, waste and unused construction materials, and other waste) totaling $4.9 \mathrm{t}-\mathrm{CO}_{2}$ equating to $109 \mathrm{kgCO}_{2}$ per m${ }^{2}$. Timber and packaging contributed to $33 \%$ and $31 \%$ of the total waste, respectively [63].

When a building reaches the end of its service life, it is demolished; the process is responsible for an emission of 0.004 to $0.01 \mathrm{~kg} \mathrm{CO} 2$ per $\mathrm{kg}$ of the concrete material. This figure depends on the type of reinforcement and structure used, in addition to the general working conditions on the site during demolition [27]. A situ-concrete type building was being demolished in Korea; it required total energy consumption of $51.5 \mathrm{MJ} / \mathrm{m}^{2}$ from diesel fuel to demolish it; thus, the level of $\mathrm{CO}_{2}$ emitted during demolition was $10.3 \mathrm{~kg}-\mathrm{CO}_{2} / 10 \mathrm{~m}^{2}$. In consideration of the $\mathrm{CO}_{2}$ that is emitted during the transportation of the demolition debris, $24.4 \mathrm{Kg}-\mathrm{CO}_{2} / 10 \mathrm{~m}^{2}, 26.3 \mathrm{~kg}-\mathrm{CO}_{2}$, and $17.6 \mathrm{~kg}-\mathrm{CO}_{2}$ were obtained for a single-family house, a flat, and a multi-family house, respectively [75]. Waste transportation consumes energy which leads to $\mathrm{CO}_{2}$ emission. According to study, during the construction period, 530 tons of waste generated and during the transportation of this waste $527 \mathrm{~L}$ of diesel oil consumed totaling $1.4 \mathrm{t}-\mathrm{CO}_{2}$ emission from the waste transportation phase [21]. 
Waste materials generated from the construction industry (concrete and concrete rubble, construction ceramics, timber and wood, glass, plastics, steel, iron, aluminum, excavated soil, and Styrofoam) or from general life can be recycled as alternative construction materials [61]. During demolition, interior finishing from buildings can be reused or recycled. To look after the environment and determine the recycling and reuse values of CDW, the waste management must be planned via volume and composition determination [76]. Concrete blocks can be crushed so that they can be used for landscaping or landfilled. The fiber generated from the carpet waste can be used in fiber reinforced concrete (FCR) and fiber reinforced soil as well. The fiber improved several mechanical properties of the concrete such as toughness, strength in tension, fatigue strength, and durability, while it reduced possible cracks and defects [77]. Waste materials can act as substitutes of concrete components; it is estimated that plastic and glass can replace fine aggregates in concrete mixes by up to $20 \%$, while waste concrete could make up for $20 \%$ of the coarse aggregate mixes in concrete [78].

Recycling one $\mathrm{kg}$ of aluminum as building demolition waste can contribute to emission reduction of $20.07 \mathrm{~kg} \mathrm{CO}_{2}$-e [79]. Demolition debris that contains steel is separated so that the steel can be sold to scrap dealers. The economically not valuable waste can be sent to dump sites [80]. When the waste steel from hoarding construction is recycled as steel scraps, $281 \mathrm{~kg} \mathrm{CO}$-e/m GHGs emission can be reduced [65]. New asphalt can be used from asphalt removed from road that is refurbished. The landscaping clearing wastes can be used as well. A portion of waste glass can be used in place of fine aggregate in asphalt paving mixtures (glassphalt) [81]. Reusing wood waste in production of particleboard reduced embodied carbon emissions up to $14.6 \%\left(-28.6 \mathrm{~kg} \mathrm{CO}_{2}-\mathrm{e} / \mathrm{m}^{2}\right)$ [50].

\section{Carbon Footprint during Operational Stage and GHGs Reduction}

Over the full cycle, building operations contribute to the $\mathrm{CO}_{2}$ balance when in service [82]. Carbon emission during operational stage of a building was a major contributor, accounting for $85.4 \%$ of the total emission followed by the construction stage which accounted for $12.6 \%$ of total emissions [83]. A high-rise residential housing block in Hong Kong demonstrated that GHG emission was estimated to about $213.03 \mathrm{t}-\mathrm{CO}_{2}-\mathrm{e} /$ flat and $4980 \mathrm{~kg} \mathrm{CO}$-e $/ \mathrm{m}^{2}$, of which $85.82 \%$ was stemming from the operating energy, $12.69 \%$ from materials, $1.14 \%$ from renovation, $0.28 \%$ from end-of-life of the building, and $0.07 \%$ from other factors [84]. The energy consumption per area of the buildings from urban, national, and global scales are $3.03 \mathrm{GJ} / \mathrm{m}^{2}, 4.27 \mathrm{GJ} / \mathrm{m}^{2}$ and $0.44 \mathrm{GJ} / \mathrm{m}^{2}$ which correspond to $0.40 \mathrm{t}-\mathrm{CO}_{2}-\mathrm{e} / \mathrm{m}^{2}, 0.14 \mathrm{t}-\mathrm{CO}_{2}-\mathrm{e} / \mathrm{m}^{2}$ and $0.04 \mathrm{t}-\mathrm{CO}_{2}-\mathrm{e} / \mathrm{m}^{2}$ greenhouse gas emissions, respectively, based on hybrid systems analysis combining input-output analysis and process analysis in China [85].

In order to contribute to $\mathrm{CO}_{2}$ reduction, new technologies were implemented in buildings. According to a study, low-carbon strategies, such as increased energy efficiency design for new buildings and energy-saving retrofit for existing buildings would decrease energy consumption by $2.98 \%$ with a carbon emission reduction of 3.15 million $\mathrm{t}-\mathrm{CO}_{2}$-e [22] Choosing correct materials, systems, and technologies which are listed in following sections at the phase of design and materials selection, will reduce energy consumption and $\mathrm{CO}_{2}$ emissions during operational stage of the buildings.

\subsection{Alternate Water Resources for Water Reuses}

Reusing water in a typical office building is estimated to conserve about $75 \%$ of the indoor potable water [86]. The average water saving of a green building was estimated to reach $37.6 \%$ with applying water efficiency technologies [87]. The rise of the water savings will reduce energy consumption and $\mathrm{CO}_{2}$ emissions [88]. The passive irrigation system has two stages: collecting water when it rains and supplying water in drought conditions [89]. Water flow in the system is natural under gravity or capillarization method [90]. A 250-room hotel in Birmingham, UK, with the rainwater recycling system saved up to $780 \mathrm{~m}^{3}$ of potable water per year [91]. According a comparative simulation 
model, gravity fed rainwater harvesting system for a high rise building in Mexico saved up to $8.5 \%$ of GHG [92]. Graywater is the water produced by bathroom, laundry machines, sinks, showers, and bathtubs [93]. Treated graywater can be reused for landscape irrigation and toilets [86].

Efficiency of water use can be improved by graywater recycling systems for flushing of toilets by dual piping, which will contribute to reducing urban water demand from $10 \%$ to $25 \%$ [94]. NH Campo de Gibraltar hotel substitutes $20 \%$ of potable water with filtered and treated grey water from showers, which resulted in a $20 \%$ reduction in annual water bill [91]. Blackwater comes from toilets and kitchens. Blackwater reuse showed a positive response from people who used automated or remotely controlled systems by the installer. Another study reported that it is costly and has poor process design [95]. Condensate recovery reuses water produced by air conditioning (AC) systems [95]. AC condensate can be used in flushing toilets, irrigation, cooling towers, roof cleaning, green roofs, and spray cooling [96].

Examples of water reuse and alternative water supplies include water conserving toilets, waterless toilets, waterless urinals, alternative shower and faucet fixtures (alternative controls, self-powering, low flow), water efficient appliances, and alternative landscaping (high efficiency irrigation, water conserving plant selection) [95]. Some statistical studies showed that water technologies increase water efficiency. For instance, urinals and commercial dishwashers showed the greatest reductions of water use, while showers and commercial toilets showed the least savings [88]. In the same manner, wastewater centralized reuse system (WWCRS) require more energy for treatment which leads to higher $\mathrm{CO}_{2}$ emissions, while the greywater decentralized reuse system (GWDRS) requires less energy (11.8-37.5\%) than WWCRS consumed [97]. A constructed wetlands system treats wastewater in a building so that it can be used in low-flow toilets and urinals, which reduces the water use in total by a percentage higher than $60 \%$ [86].

\subsection{Heating, Ventilation and Air Conditioning}

Heating, ventilation, and air conditioning (HVAC) systems of buildings consume about $40-60 \%$ of total energy taking into consideration the embodied energy which stems from the production of the building [98]. Owing to their large thermal mass, concrete and other heavy weight materials positively impact the energy consumption of buildings; for a heavy weight building (based on concrete frame), energy needed for heating/cooling/ventilation is $10 \mathrm{MJ} / \mathrm{m}^{2}$ resulting in $1.3 \mathrm{CO}_{2} / \mathrm{m}^{2}$; and for light-weight building, (based on plaster boards stud walls), it is $20 \mathrm{MJ} / \mathrm{m}^{2}$ resulting in $2.6 \mathrm{CO}_{2} / \mathrm{m}^{2}$ in Northern Europe [27].

Equipment sizing and selection, pipe/duct sizing, energy performance analysis, system optimization, real-time performance optimization, control analysis, control optimization, and simulation and programming for HVAC systems can reduce energy consumption and increase the comfort of residents $[99,100]$. According to a study, using a high energy performance air conditioner resulted in $7664.4 \mathrm{t}-\mathrm{CO}_{2}$-e reduction in an office building in Nanhaiyiki 3, China; $451.5 \mathrm{t}-\mathrm{CO}_{2}$-e reduction in a Pixel building in Australia during the life cycle of the buildings. In the same fashion, using natural ventilation and lighting resulted in a $5687.6 \mathrm{t}-\mathrm{CO}_{2}$-e reduction in Nanhaiyiki 3, China; $4649.8 \mathrm{t}-\mathrm{CO}_{2}$-e reduction in the Pixel building in Australia during the life cycle of the buildings [60].

\subsection{Other Building Systems and Technologies}

There are various technologies and systems that can be applied to enhance the efficiency of buildings and decrease $\mathrm{CO}_{2}$ emissions. Such innovations include: windows and building surfaces with tunable optical properties; high-efficiency heat pumps; highly efficient lighting devices; thin insulating materials; improved software for analyzing building design and operations; inexpensive, energy harvesting sensors and controls; optimized control strategies; and interoperable building communication systems [101]. A study was conducted to compare different systems in a building, and it found that systems like in- 
terior lights $(-150 \%)$, mechanical ventilation $(-25 \%)$, and pumps $(-11 \%)$ had the least energy savings whereas systems like interior fans $(100 \%)$, heat rejection units $(56 \%)$ and receptacle equipment $(33 \%)$ had the highest energy savings. The negative values show that the systems are less efficient when compared to the baseline [82]. In another study, it was found that using renewable energies such as a solar photovoltaic system, wind turbine, and anaerobic digester resulted in $1204.1 \mathrm{t}-\mathrm{CO}_{2}$-e reduction in an office building in Australia, and using renewable energy such as a solar photovoltaic system, a solar thermal water system, and a ground source heat pump resulted in $2871.6 \mathrm{t}-\mathrm{CO}_{2}-\mathrm{e}$ reduction in an office building in China during the life cycle of the buildings [60]. Expanded polystyrene (EPS), cellulose, and elastomer as insulation and sealing materials resulted in an average $3.5 \mathrm{~kg} \mathrm{CO} 2-\mathrm{e} / \mathrm{kg}$ emission, some insulation materials such as sheep's wool could reduce its impact up to $98 \%$ [50].

\section{Discussion}

Globally, in the developed and developing countries, the whole process of construction and building operations contributes to $33 \%$ of greenhouse gas (GHG) emissions and $40 \%$ of global energy consumption, stemming from the usage of the equipment, transportation, and the manufacturing of building materials. The urban population is increasing, which leads to more construction in the future and increased GHGs emissions [6]. Therefore, new policies are required for mitigation of GHG emissions. Regulations such as building codes can effectively reduce GHG emissions if enforced well enough and can ensure new buildings incorporate designs that are both cost and energy effective. However, regulations alone can result in extra costs for the governments, and they should be designed to cover all aspects of GHG emission activities [7]. Moreover, this policy instrument has been widely criticized for being inflexible, complex and for not taking into consideration differences in technology and geography [102].

On the other hand, a carbon tax is simpler to design, has relatively low administration costs and is attractive to stakeholders in the building sector due to their familiarity with the tax mechanism. The revenues earned from carbon tax can be redistributed to other policy instruments such as incentives [7]. However, establishing an appropriate tax rate can be a challenging task for governments as it involves complete knowledge of costs of mitigation, the growth of the economy, progresses in technology and other factors which need to be taken into consideration. Moreover, due to opposition from the public and also to avoid pressuring the construction industry intensively, governments could also face problems in establishing a deterring tax rate that can reduce GHG emissions [102].

The cumulative amount of GHG emissions mitigated can be quantified with ETS and emission permits can be distributed for free or auctioned off. However, there are concerns of market failures and regulatory based loop holes because the construction sectors lacks proper GHG accounting [12]. It is necessary to move beyond the debate of policy instruments in order to be able to pinpoint the factors that are actually slowing the move to a carbon neutral construction industry. One of the common cited barriers to carbon reduction schemes in the construction industry is the incremental cost associated with it $[103,104]$. Studies have shown that building contractors and developers often overestimate the cost associated with energy efficiency [105]. For example, in Germany, new buildings with very little heating requirements can be constructed with an extra cost of no more than $5-12 \%$, while, in Northern China, a building project was able to achieve reductions of $65 \%$ in heating consumption with an extra cost of no more than $8 \%$ without compromising thermal comfort $[103,106]$. Therefore, correct estimations are important for cost estimations.

Other cited barriers to carbon reduction in construction industry were the skills and knowledge gap of not only the designers and contractors but also of the end users, i.e., the occupants of the buildings [104,107]. As a conclusion, each instrument has some limitations; therefore, a variety of economic, environmental, political, and social factors need to be taken into consideration [7]. Training and education should be emphasized as important ways to 
reduce GHG emissions in the construction industry by enabling behavioral changes within organizations. In this context, identifying sources of the carbon footprint at the different stages during construction and showing possible carbon reduction technologies/systems and techniques as summarized in Table 4 will be helpful for awareness and to fulfill the knowledge gap at the design stage from clients to designers and contractors.

Table 4. Summary of findings.

\begin{tabular}{|c|c|c|c|c|}
\hline Building Operations & $\mathrm{CO}_{2}$ Emission & Reduction Material/Techniques & $\mathrm{CO}_{2}$ Reduction & References \\
\hline Limestone quarrying & $\begin{array}{l}3.13 \mathrm{~kg} \mathrm{CO} \text {-e per ton } \\
\text { crushed rock product }\end{array}$ & $\begin{array}{l}\text { Application of alternative/ renewable } \\
\text { energy such as solar thermal and } \\
\text { biodiesel as compared to acquiring } \\
\text { energy needs for quarrying from the grid } \\
\text { or natural gas }\end{array}$ & $\begin{array}{l}\text { More than } 81 \% \text { reduction in } \\
\text { GHG emissions annually }\end{array}$ & [24] \\
\hline $\begin{array}{l}\text { Portland clinker } \\
\text { manufacturing }\end{array}$ & $\begin{array}{l}\text { nearly } 1 \mathrm{~kg} \text { of } \mathrm{CO}_{2} \text { per one } \\
\mathrm{kg} \text { of Portland clinker }(\mathrm{b})\end{array}$ & $\begin{array}{l}\text { Alternative clinker substitution-use of } \\
\text { calcium carbide residue in replacement } \\
\text { of limestone partially }\end{array}$ & $\begin{array}{c}374 \mathrm{~kg} \mathrm{CO} / \text { ton of clinker } \\
\text { annually, or more than } 37 \% \\
\text { reduction in } \mathrm{CO}_{2} \text { emissions } \\
\text { per ton of clinker }\end{array}$ & {$[26,39]$} \\
\hline \multirow[t]{3}{*}{ Asphalt } & \multirow[t]{2}{*}{$\begin{array}{l}0.05 \mathrm{ppm} \text { of } \mathrm{CO}_{2} \text { per ton } \\
\text { per year for conventional } \\
\text { asphalt production }\end{array}$} & $\begin{array}{l}\text { Sasobit additives with Warm } \\
\text { Mix Asphalt }\end{array}$ & $\begin{array}{l}0.003 \mathrm{ppm} \text { to } 0.004 \mathrm{ppm} \text { of } \\
\mathrm{CO}_{2} \text { per ton or more than } 94 \% \\
\text { reduction in } \mathrm{CO}_{2} \text { emissions } \\
0.005 \mathrm{ppm} \text { to } 0.0054 \mathrm{ppm} \text { of }\end{array}$ & {$[38,51]$} \\
\hline & & Sasobit additives with Hot Mix Asphalt & $\begin{array}{l}\mathrm{CO}_{2} / \text { ton, or more than } 90 \% \\
\text { reduction in } \mathrm{CO}_{2} \text { emissions }\end{array}$ & [38] \\
\hline & $\begin{array}{c}132 \mathrm{~kg} \mathrm{CO} \text { equivalent } \\
\text { /ton of virgin } \\
\text { asphalt produced }\end{array}$ & Reclaimed asphalt pavement & $\begin{array}{c}\text { Dropped to average of } \\
84.35 \mathrm{~kg} \mathrm{CO} \text { equivalent/ton, } \\
\text { or more than } 36 \% \text { reduction in } \\
\mathrm{CO}_{2} \text { emissions }\end{array}$ & {$[3,56]$} \\
\hline \multirow{2}{*}{ Concrete } & $\begin{array}{l}5 \mathrm{w} / \mathrm{c} \text { were between } 347 \\
\text { and } 351 \mathrm{~kg} \text { of } \mathrm{CO}_{2}-\mathrm{e} / \mathrm{m}^{3}\end{array}$ & Recycled coarse aggregates & Reduce 0.03 tons of $\mathrm{CO}_{2}-\mathrm{e} / \mathrm{m}^{3}$ & {$[56,58]$} \\
\hline & $293 \mathrm{~kg}$ of $\mathrm{CO}_{2}-\mathrm{e} / \mathrm{m}^{3}$ & $\begin{array}{l}\text { Fractional replacement of cement in } \\
\text { concrete with fly-ash and ground } \\
\text { granulated blast furnace slag and natural } \\
\text { aggregates with recycle } \\
\text { crushed aggregate }\end{array}$ & $\begin{array}{l}\text { Reductions of up to } 3.8 \% \\
\quad\left(10.5 \mathrm{~kg} \mathrm{CO}-\mathrm{e} / \mathrm{m}^{3}\right)\end{array}$ & [47] \\
\hline \multirow[t]{3}{*}{$\begin{array}{l}\text { Onsite construction } \\
\text { process }\end{array}$} & $\begin{array}{l}\text { (a) During idling, at a fuel } \\
\text { consumption rate of } \\
0.84 \text { gal/hour, } 2.7 \mathrm{~kg} \\
\mathrm{CO}_{2} / \text { liter was produced } \\
\text { Traditional building with }\end{array}$ & $\begin{array}{l}\text { Reducing idling time by using direct } \\
\text { fired heaters instead of diesel engines }\end{array}$ & $\begin{array}{l}\text { Direct fired heaters can reduce } \\
\mathrm{NOx} \text { and } \mathrm{CO}_{2} \text { emissions by } \\
99 \% \text { and } 94-96 \% \text { respectively } \\
\text { during idling time }\end{array}$ & [70] \\
\hline & $\begin{array}{l}\text { steel products or concrete } \\
\text { produces } 366 \mathrm{~kg} \\
\mathrm{CO}_{2}-\mathrm{e} / \mathrm{m}^{2} \text { total embodied } \\
\text { carbon emissions }\end{array}$ & $\begin{array}{l}\text { Using prefabricated wood instead of } \\
\text { steel or concrete }\end{array}$ & $\begin{array}{l}25 \% \text { reduction in total } \\
\text { GHG emissions }\end{array}$ & {$[47,64]$} \\
\hline & $\begin{array}{l}\text { 3-bedroom semi-detached } \\
\text { house constructed using } \\
\text { traditional masonry } \\
\text { construction produces } \\
405 \mathrm{~kg} \mathrm{CO} 2 / \mathrm{m}^{2}\end{array}$ & $\begin{array}{l}\text { using offsite panelized timber frame and } \\
\text { modern methods of construction }\end{array}$ & $\begin{array}{l}34 \% \text { reduction in total } \\
\text { embodied carbon emissions }\end{array}$ & {$[61]$} \\
\hline \multirow{3}{*}{$\begin{array}{l}\text { Construction, } \\
\text { demolition waste }\end{array}$} & \multirow{3}{*}{$\begin{array}{l}0.004 \text { to } 0.01 \mathrm{~kg} \mathrm{CO}_{2} \\
\text { per kg of the } \\
\text { demolition waste }\end{array}$} & $\begin{array}{l}\text { Recycling building demolition waste } \\
\text { such as aluminum }\end{array}$ & $\begin{array}{l}20.07 \mathrm{~kg} \mathrm{CO}_{2} \text {-e per } \mathrm{kg} \text { of } \\
\text { aluminum recycled }\end{array}$ & {$[26,78]$} \\
\hline & & $\begin{array}{l}\text { Recycling waste steel from hoarding } \\
\text { construction as steel scraps }\end{array}$ & & {$[64]$} \\
\hline & & $\begin{array}{l}\text { Reusing wood waste into production-use } \\
\text { of particleboard }\end{array}$ & $\begin{array}{c}14.6 \% \text { reduction in } \mathrm{CO}_{2} \\
\text { emissions }(-28.6 \mathrm{~kg} \\
\left.\mathrm{CO}_{2}-\mathrm{e} / \mathrm{m}^{2}\right)\end{array}$ & {$[47]$} \\
\hline \multirow[t]{4}{*}{$\begin{array}{l}\text { Building's operations } \\
\text { when in service }\end{array}$} & \multirow[t]{4}{*}{$\begin{array}{l}\text { Account for } 85.4 \% \text { of the } \\
\text { total emissions of a } \\
\text { building's life cycle }\end{array}$} & $\begin{array}{l}\text { High energy performance air-conditioner } \\
\text { Utilization of renewable energy such as a } \\
\text { solar photovoltaic system, solar thermal } \\
\text { water system, and a ground source } \\
\text { heat pump }\end{array}$ & $4.6 \mathrm{~kg} \mathrm{CO}-\mathrm{eq} / \mathrm{m}^{2}$ & \multirow[t]{4}{*}[47,48,82]{} \\
\hline & & $\begin{array}{l}\text { Use of natural ventilation and lighting } \\
\text { Use of sheep's wool as insulation } \\
\text { material in buildings }\end{array}$ & $\begin{array}{l}9.1 \mathrm{~kg} \mathrm{CO}-\mathrm{eq} / \mathrm{m}^{2} \\
98 \% \text { reduction in } \\
\text { GHG emissions }\end{array}$ & \\
\hline & & $\begin{array}{c}\text { Applying large thermal mass, concrete, } \\
\text { and other heavy weight materials for } \\
\text { reduction of HVAC energy }\end{array}$ & $\begin{array}{l}50 \% \text { reduction in } \\
\mathrm{CO}_{2} \text { emissions } / \mathrm{m}^{2}\end{array}$ & \\
\hline & & Rainwater harvesting system & $8.5 \%$ reduction of GHG & \\
\hline
\end{tabular}




\section{Conclusions}

GHG emissions mitigation can be achieved by indirect pricing such as regulations and direct pricing such as carbon tax and emission trading schemes (ETS). However, regulations can be inflexible, complex, and may not take into consideration differences in technology and geography. In addition, ETS can be complex because the construction sector lacks proper GHG accounting. Therefore, increasing the awareness, education, and incentives can lessen the carbon footprint of construction industry. Consequently, we aimed to increase awareness of the carbon footprint sources in construction and building operations during manufacturing, transportation, construction, operations/management, and end-of-life deconstruction. As a result, various carbon reduction techniques/systems were identified. It was found that mining and manufacturing of materials and chemicals contributed to high energy usage and $90 \%$ of the total $\mathrm{CO}_{2}$ emissions. Therefore,

- Testing different blends of cement with addition of alternative additives such as alkali-activated slag mortars or fly ash in concrete;

- Changing cement production methods;

- Addition of Sasobit or reclaimed asphalt pavement in asphalt mixtures;

- Recycling building wastes such as concrete aggregate and recycled asphalt in common construction materials;

- Conversion from the wet process to the dry process in concrete manufacturing;

- Substitution of lower carbon content fuels for coal, coke, and petroleum coke;

- Alternate options in terms of vehicle type, engine power, truck capacity, and fuel type to improve the fuel efficiency in the construction vehicles;

- $\quad$ Reducing idle time by using direct fired heaters, auxiliary power units (APU), thermal storage systems, on-board batteries, and automatic engine shut-off devices;

- Applications of alternate water resources for water reuse purposes;

- Switching to efficient HVAC systems; and

- Utilization of different building operations/systems will lessen energy consumption and reduce GHG emissions up to $90 \%$ in different stages in construction industry.

This review can be useful at the stage of conceptualization, design, and construction to assist clients and stakeholders in selecting materials and systems. There is large scope for further research on how to decrease carbon footprint in construction. Some of the areas that require attention include:

- improving recyclable waste materials such as glass, rubber crumbs, etc., as construction materials;

- developing decision making tools for effective carbon footprinting;

- creating inventory databases for Life Cycle Assessment for each alternative material's embodied carbon value.

Author Contributions: Conceptualization, B.S. and Y.F.; formal analysis, B.S. and Y.F.; resources, Y.F., C.-S.C. and I.Y.; writing—original draft preparation, B.S. and Y.F.; writing—review and editing, C.-S.C., I.Y. and Y.-J.B.; project administration, B.S.; funding acquisition, B.S. All authors have read and agreed to the published version of the manuscript.

Funding: This research was funded by the Khalifa University, KUIRF L1 210045 grant.

Institutional Review Board Statement: Not applicable.

Informed Consent Statement: Not applicable.

Data Availability Statement: Not applicable.

Acknowledgments: The authors would like to extend gratitude to the following students for their assistance: Tethkar Alhammadi, Madeya Al Mehairbi, Fatmah Aldhanhani, and Fatima Almusharrekh.

Conflicts of Interest: The authors declare no conflict of interest. 


\section{References}

1. Solís-Guzmán, J.; Martínez-Rocamora, A.; Marrero, M. Methodology for determining the carbon footprint of the construction of residential buildings. In Assessment of Carbon Footprint in Different Industrial Sectors; Springer: Singapore, 2014; Volume 1, pp. 49-83.

2. WEF. Shaping the Future of Construction: A Breakthrough in Mindset and Technology; WEF Cologny: Geneva, Switzerland, 2016.

3. Yan, H.; Shen, Q.; Fan, L.C.H.; Wang, Y.; Zhang, L. Greenhouse gas emissions in building construction: A case study of One Peking in Hong Kong. Build. Environ. 2010, 45, 949-955. [CrossRef]

4. Kisku, N.; Joshi, H.; Ansari, M.; Panda, S.; Nayak, S.; Dutta, S.C. A critical review and assessment for usage of recycled aggregate as sustainable construction material. Constr. Build. Mater. 2017, 131, 721-740. [CrossRef]

5. Huang, L.; Krigsvoll, G.; Johansen, F.; Liu, Y.; Zhang, X. Carbon emission of global construction sector. Renew. Sustain. Energy Rev. 2018, 81, 1906-1916. [CrossRef]

6. Mardiana, A.; Riffat, S. Building energy consumption and carbon dioxide emissions: Threat to climate change. J. Earth Sci. Clim. Chang. 2015, 1-3.

7. Wang, T.; Foliente, G.; Song, X.; Xue, J.; Fang, D. Implications and future direction of greenhouse gas emission mitigation policies in the building sector of China. Renew. Sustain. Energy Rev. 2014, 31, 520-530. [CrossRef]

8. Iwaro, J.; Mwasha, A. A review of building energy regulation and policy for energy conservation in developing countries. Energy Policy 2010, 38, 7744-7755. [CrossRef]

9. Wong, P.S.; Ng, S.T.; Shahidi, M. Towards understanding the contractor's response to carbon reduction policies in the construction projects. Int. J. Proj. Manag. 2013, 31, 1042-1056. [CrossRef]

10. King, D. Engineering a Low Carbon Built Environment: The Discipline of Building Engineering Physics; Royal Academy of Engineering: London, UK, 2010.

11. Hahn, R.W. Greenhouse gas auctions and taxes: Some political economy considerations. Rev. Environ. Econ. Policy 2009, 3, 167-188. [CrossRef]

12. Spash, C.L. The brave new world of carbon trading. New Political Econ. 2010, 15, 169-195. [CrossRef]

13. Lu, Y.; Zhu, X.; Cui, Q. Effectiveness and equity implications of carbon policies in the United States construction industry. Build. Environ. 2012, 49, 259-269. [CrossRef]

14. Burtraw, D.; Palmer, K. Compensation rules for climate policy in the electricity sector. J. Policy Anal. Manag. J. Assoc. Public Policy Anal. Manag. 2008, 27, 819-847. [CrossRef]

15. Figueres, C.; Bosi, M. Achieving Greenhouse Gas Emission Reductions in Developing Countries through Energy Efficient Lighting Projects in the Clean Development Mechanism (CDM); Unit, T.C.F., Ed.; World Bank: Washington, DC, USA, 2006.

16. Chan, E.H.; Qian, Q.K.; Lam, P.T. The market for green building in developed Asian cities-The perspectives of building designers. Energy Policy 2009, 37, 3061-3070. [CrossRef]

17. Jiang, P.; Tovey, N.K. Opportunities for low carbon sustainability in large commercial buildings in China. Energy Policy 2009, 37, 4949-4958. [CrossRef]

18. Wang, X.; Duan, Z.; Wu, L.; Yang, D. Estimation of carbon dioxide emission in highway construction: A case study in southwest region of China. J. Clean. Prod. 2015, 103, 705-714. [CrossRef]

19. Fischedick, M.; Roy, J.; Acquaye, A.; Allwood, J.; Ceron, J.-P.; Geng, Y.; Kheshgi, H.; Lanza, A.; Perczyk, D.; Price, L. Industry In: Climate Change 2014: Mitigation of Climate Change; Intergovernmental Panel on Climate Change: Cambridge, United Kingdom; Cambridge University Press: New York, NY, USA, 2014.

20. Jafary Nasab, T.; Monavari, S.M.; Jozi, S.A.; Majedi, H. Assessment of carbon footprint in the construction phase of high-rise constructions in Tehran. Int. J. Environ. Sci. Technol. 2020, 17, 3153-3164. [CrossRef]

21. Seo, M.-S.; Kim, T.; Hong, G.; Kim, H. On-Site Measurements of CO2 Emissions during the Construction Phase of a Building Complex. Energies 2016, 9, 599. [CrossRef]

22. Huang, W.; Li, F.; Cui, S.-H.; Li, F.; Huang, L.; Lin, J.-Y. Carbon Footprint and Carbon Emission Reduction of Urban Buildings: A Case in Xiamen City, China. Procedia Eng. 2017, 198, 1007-1017. [CrossRef]

23. Li, D.Z.; Chen, H.X.; Hui, E.C.M.; Zhang, J.B.; Li, Q.M. A methodology for estimating the life-cycle carbon efficiency of a residential building. Build. Environ. 2013, 59, 448-455. [CrossRef]

24. Choate, W.T. Energy and Emission Reduction Opportunities for the Cement Industry; BCS Inc.: Laurel, MD, USA, 2003 ; p. 1218753.

25. Kittipongvises, S. Assessment of environmental impacts of limestone quarrying operations in Thailand. Environ. Clim. Technol. 2017, 20, 67-83. [CrossRef]

26. Ma, F.; Sha, A.; Yang, P.; Huang, Y. The Greenhouse Gas Emission from Portland Cement Concrete Pavement Construction in China. Int. J. Environ. Res. Public Health 2016, 13, 632. [CrossRef] [PubMed]

27. Nielsen, C.V. Carbon footprint of concrete buildings seen in the life cycle perspective. In Proceedings of the NRMCA 2008 Concrete Technology Forum: Focus on Sustainable Development, Denver, CO, USA, 20-22 May 2008; pp. 1-14.

28. Gibson, S.; Strachan, P. Reducing the Embodied Carbon Content of Asphalt; University of Strathclyde: Glasgow, Scotland, 2011.

29. Miller, S.A.; Horvath, A.; Monteiro, P.J.; Ostertag, C.P. Greenhouse gas emissions from concrete can be reduced by using mix proportions, geometric aspects, and age as design factors. Environ. Res. Lett. 2015, 10, 114017. [CrossRef] 
30. Chehovits, J.; Galehouse, L. Energy usage and greenhouse gas emissions of pavement preservation processes for asphalt concrete pavements. In Proceedings of the 1st International Conference of Pavement Preservation, Newport Beach, CA, USA, 13-15 April 2010; pp. 27-42.

31. Peng, B.; Cai, C.; Yin, G.; Li, W.; Zhan, Y. Evaluation system for $\mathrm{CO}_{2}$ emission of hot asphalt mixture. J. Traffic Transp. Eng. (Engl. Ed.) 2015, 2, 116-124. [CrossRef]

32. Ma, F.; Sha, A.; Lin, R.; Huang, Y.; Wang, C. Greenhouse gas emissions from asphalt pavement construction: A case study in China. Int. J. Environ. Res. Public Health 2016, 13, 351. [CrossRef] [PubMed]

33. International Energy Agency. Greenhouse Gas Emissions from Major Industrial Sources III-Iron and Steel Production Report PH3/30; International Energy Agency Greenhouse Gas R\&D Programme; Stoke Orchard: Cheltenham, UK, 2000.

34. Worrell, E.; Blinde, P.; Neelis, M.; Blomen, E.; Masanet, E. Energy Efficiency Improvement and Cost Saving Opportunities for the US Iron and Steel Industry an ENERGY STAR (R) Guide for Energy and Plant. Managers; Lawrence Berkeley National Lab. (LBNL): Berkeley, CA, USA, 2010.

35. Danielsen, S.; Gränne, F.; Hólmgeirsdóttir, P.; Jonsson, G.; Krage, G.; Mathiesen, D.; Nielsen, C.; Wigum, B. Best Available Technology Report for the Aggregate and Concrete Industries in Europe. ECO-SERVE Netw. 2006, 3, 99-108.

36. Naqi, A.; Jang, J.G. Recent progress in green cement technology utilizing low-carbon emission fuels and raw materials: A review. Sustainability 2019, 11, 537. [CrossRef]

37. Deolalkar, S.; Shah, A.; Davergave, N. Designing Green Cement Plants; Butterworth-Heinemann: Oxford, UK, 2015.

38. Abdul-Wahab, S.A.; Hassan, E.M.; Al-Jabri, K.S.; Yetilmezsoy, K. Application of zeolite/kaolin combination for replacement of partial cement clinker to manufacture environmentally sustainable cement in Oman. Environ. Eng. Res. 2019, $24,246-253$. [CrossRef]

39. Kumar, R.; Kumar, S.; Mehrotra, S. Towards sustainable solutions for fly ash through mechanical activation. Resour. Conserv. Recycl. 2007, 52, 157-179. [CrossRef]

40. Mikhailova, O.; Šimonová, H.; Topolář, L.; Rovnaník, P. Influence of Polymer Additives on Mechanical Fracture Properties and on Shrinkage of Alkali Activated Slag Mortars. Key Eng. Mater. 2018, 761, 39-44. [CrossRef]

41. LeBlanc, A.; Keches, C.M. Reducing Greenhouse Gas Emissions from Asphalt Materials; Worcester Polytechnic Institute: Worcester, MA, USA, 2007.

42. Hasanbeigi, A.; Price, L.; Lin, E. Emerging energy-efficiency and $\mathrm{CO}_{2}$ emission-reduction technologies for cement and concrete production: A technical review. Renew. Sustain. Energy Rev. 2012, 16, 6220-6238. [CrossRef]

43. Worrell, E.; Galitsky, C. Energy Efficiency Improvement and Cost Saving Opportunities for Cement Making; Ernest Orlando Lawrence Berkeley National Laboratory, University of California: Berkeley, CA, USA, 2008.

44. Barnett, K.; Torres, E. Available and Emerging Technologies for Reducing Greenhouse Gas Emissions from the Portland Cement Industry; United States Environmental Protection Agency: Research Triangle Park, NC, USA, 2010.

45. D'Alessandro, A.; Pisello, A.; Fabiani, C.; Ubertini, F.; Cabeza, L.; Cotana, F.; Materazzi, A. Innovative Structural Concretes with Phase Change Materials for Sustainable Constructions: Mechanical and Thermal Characterization. In Proceedings of the Conference on Italian Concrete Days, Lecco, Italy, 14-15 June 2018; pp. 172-183.

46. Toledo Filho, R.; Koenders, E.; Formagini, S.; Fairbairn, E. Performance assessment of ultra high performance fiber reinforced cementitious composites in view of sustainability. Mater. Des. 2012, 36, 880-888. [CrossRef]

47. Cheah, C.B.; Part, W.K.; Ramli, M. The long term engineering properties of cementless building block work containing large volume of wood ash and coal fly ash. Constr. Build. Mater. 2017, 143, 522-536. [CrossRef]

48. Ballari, M.M.; Hunger, M.; Hüsken, G.; Brouwers, H. NOx photocatalytic degradation employing concrete pavement containing titanium dioxide. Appl. Catal. B Environ. 2010, 95, 245-254. [CrossRef]

49. Biswas, W.K. Carbon footprint and embodied energy consumption assessment of building construction works in Western Australia. Int. J. Sustain. Built Environ. 2014, 3, 179-186. [CrossRef]

50. Padilla-Rivera, A.; Amor, B.; Blanchet, P. Evaluating the Link between Low Carbon Reductions Strategies and Its Performance in the Context of Climate Change: A Carbon Footprint of a Wood-Frame Residential Building in Quebec, Canada. Sustainability 2018, 10, 2715. [CrossRef]

51. Shafabakhsh, G.; Taghipoor, M.; Sadeghnejad, M.; Tahami, S. Evaluating the effect of additives on improving asphalt mixtures fatigue behavior. Constr. Build. Mater. 2015, 90, 59-67. [CrossRef]

52. Koga, N.; Tsuru, K.; Takahashi, I.; Ishikawa, K. Effects of humidity on calcite block fabrication using calcium hydroxide compact. Ceram. Int. 2015, 41, 9482-9487. [CrossRef]

53. Sharma, A.; Lee, B.-K. Energy savings and reduction of $\mathrm{CO}_{2}$ emission using $\mathrm{Ca}(\mathrm{OH})_{2}$ incorporated zeolite as an additive for warm and hot mix asphalt production. Energy 2017, 136, 142-150. [CrossRef]

54. BDA. Brick Industry Sustainability. Available online: http://www.brick.org.uk/resources/brick-industry/sustainability/2010 (accessed on 12 July 2020).

55. Seco, A.; Urmeneta, P.; Prieto, E.; Marcelino, S.; García, B.; Miqueleiz, L. Estimated and real durability of unfired clay bricks: Determining factors and representativeness of the laboratory tests. Constr. Build. Mater. 2017, 131, 600-605. [CrossRef]

56. Espuelas, S.; Omer, J.; Marcelino, S.; Echeverría, A.M.; Seco, A. Magnesium oxide as alternative binder for unfired clay bricks manufacturing. Appl. Clay Sci. 2017, 146, 23-26. [CrossRef] 
57. Miqueleiz, L.; Ramírez, F.; Seco, A.; Nidzam, R.; Kinuthia, J.; Tair, A.A.; Garcia, R. The use of stabilised Spanish clay soil for sustainable construction materials. Eng. Geol. 2012, 133, 9-15. [CrossRef]

58. Meyer, C. Concrete and sustainable development. ACI Spec. Publ. 2002, 206, 501-512.

59. Heidari, B.; Marr, L.C. Real-time emissions from construction equipment compared with model predictions. J. Air Waste Manag. Assoc. 2015, 65, 115-125. [CrossRef]

60. Wang, T.; Seo, S.; Liao, P.-C.; Fang, D. GHG emission reduction performance of state-of-the-art green buildings: Review of two case studies. Renew. Sustain. Energy Rev. 2016, 56, 484-493. [CrossRef]

61. Bolden, J.; Abu-Lebdeh, T.; Fini, E. Utilization of recycled and waste materials in various construction applications. Am. J. Environ. Sci. 2013, 9, 14-24. [CrossRef]

62. FHWA. User Guidelines for Waste and Byproduct Materials in Pavement Construction; FHWA: Washington, DC, USA, 2012.

63. Monahan, J.; Powell, J.C. An embodied carbon and energy analysis of modern methods of construction in housing: A case study using a lifecycle assessment framework. Energy Build. 2011, 43, 179-188. [CrossRef]

64. Zhang, B.; Ariaratnam, S.T.; Wu, J. Estimation of $\mathrm{CO}_{2}$ Emissions in a Wastewater Pipeline Project. In Proceedings of the International Conference on Pipelines and Trenchless Technology, Wuhan, China, 19-22 October 2012; pp. 521-531.

65. Hossain, M.U.; Poon, C.S. Global warming potential and energy consumption of temporary works in building construction: A case study in Hong Kong. Build. Environ. 2018, 142, 171-179. [CrossRef]

66. Palaniappan, S.; Bashford, H.; Fafitis, A.; Li, K.; Stecker, L. Carbon emissions based on ready-mix concrete transportation: A production home building case study in the Greater Phoenix Arizona area. In Proceedings of the Associated Schools of Construction 45th Annual International Conference, Gainesville, FL, USA, 1-4 April 2009.

67. Abolhasani, S.; Frey, H.C.; Kim, K.; Rasdorf, W.; Lewis, P.; Pang, S.-H. Real-World In-Use Activity, Fuel Use, and Emissions for Nonroad Construction Vehicles: A Case Study for Excavators. J. Air Waste Manag. Assoc. 2008, 58, 1033-1046. [CrossRef]

68. Lewis, P.; Leming, M.; Rasdorf, W. Impact of Engine Idling on Fuel Use and $\mathrm{CO}_{2}$ Emissions of Nonroad Diesel Construction Equipment. J. Manag. Eng. 2012, 28, 31-38. [CrossRef]

69. Melanta, S.; Miller-Hooks, E.; Avetisyan, H.G. Carbon Footprint Estimation Tool for Transportation Construction Projects. J. Constr. Eng. Manag. 2013, 139, 547-555. [CrossRef]

70. Kolpakov, A.; Reich, S.L. Synthesis of Research on the Use of Idle Reduction Technologies in Transit; University of South Florida, Center for Urban Transportation Research: Tampa, FL, USA, 2015.

71. Shancita, I.; Masjuki, H.; Kalam, M.; Fattah, I.R.; Rashed, M.; Rashedul, H. A review on idling reduction strategies to improve fuel economy and reduce exhaust emissions of transport vehicles. Energy Convers. Manag. 2014, 88, 794-807. [CrossRef]

72. Cochran, K.; Townsend, T.G. Estimating construction and demolition debris generation using a materials flow analysis approach. Waste Manag. Res. 2010, 30, 2247-2254. [CrossRef]

73. Jiménez, L.F.; Domínguez, J.A.; Vega-Azamar, R.E. Carbon Footprint of Recycled Aggregate Concrete. Adv. Civil. Eng. 2018, 2018, 1-6. [CrossRef]

74. Solis-Guzman, J.; Marrero, M. Ecological Footprint Assessment of Building Construction; Bentham Science Publishers: Sharjah, United Arab Emirates, 2015.

75. Seo, S.; Hwang, Y. Estimation of $\mathrm{CO}_{2}$ Emissions in Life Cycle of Residential Buildings. J. Constr. Eng. Manag. 2001, 127, 414-418. [CrossRef]

76. Lage, I.M.; Abella, F.M.; Herrero, C.V.; Ordóñez, J.L.P. Estimation of the annual production and composition of C\&D Debris in Galicia (Spain). Waste Manag. 2010, 30, 636-645.

77. Wang, Y. Chapter 14: Utilization of Recycled Carpet Waste Fibers for Reinforcement of Concrete and Soil. In Recycling in Textiles; Woodhead Publishing: Cambridge, UK, 2006.

78. Batayneh, M.; Marie, I.; Asi, I. Use of selected waste materials in concrete mixes. Waste Manag. Res. 2007, 27, 1870-1876. [CrossRef] [PubMed]

79. Wang, J.; Wu, H.; Duan, H.; Zillante, G.; Zuo, J.; Yuan, H. Combining life cycle assessment and Building Information Modelling to account for carbon emission of building demolition waste: A case study. J. Clean. Prod. 2018, 172, 3154-3166. [CrossRef]

80. Islam, R.; Nazifa, T.H.; Yuniarto, A.; Uddin, A.S.; Salmiati, S.; Shahid, S. An empirical study of construction and demolition waste generation and implication of recycling. Waste Manag. 2019, 95, 10-21. [CrossRef] [PubMed]

81. Salem, Z.T.A.; Khedawi, T.S.; Baker, M.B.; Abendeh, R. Effect of waste glass on properties of asphalt concrete mixtures. Jordan J. Civil. Eng. 2017, 11, 117-131.

82. Ramachanderan, S.S.; Venkiteswaran, V.K.; Chuen, Y.T. Carbon $\left(\mathrm{CO}_{2}\right)$ Footprint Reduction Analysis for Buildings through Green Rating Tools in Malaysia. Energy Procedia 2017, 105, 3648-3655. [CrossRef]

83. Peng, C.; Wu, X. Case study of carbon emissions from a building's life cycle based on BIM and Ecotect. Adv. Mater. Science. Eng. 2015, 1-15. [CrossRef]

84. Yim, S.Y.C.; Ng, S.T.; Hossain, M.U.; Wong, J.M.W. Comprehensive Evaluation of Carbon Emissions for the Development of High-Rise Residential Building. Buildings 2018, 8, 147. [CrossRef]

85. Li, Y.L.; Han, M.Y.; Liu, S.Y.; Chen, G.Q. Energy consumption and greenhouse gas emissions by buildings: A multi-scale perspective. Build. Environ. 2019, 151, 240-250. [CrossRef]

86. Kehoe, P.; Rhodes, S. Pushing the conservation envelope through the use of alternate water sources. J.-Am. Water Work. Assoc. 2013, 105, 46-50. [CrossRef] 
87. Cheng, C.-L. Evaluation of Water Efficiency in Green Building in Taiwan. Water 2016, 8, 236. [CrossRef]

88. Dyballa, C.; Hoffman, H.W.B. The Role of Water Efficiency in Future Water Supply. J.-Am. Water Work. Assoc. 2015, 107, 35-44. [CrossRef]

89. Moise, G. Passive irrigation system for green roofs. Sci. Pap. Ser. Manag. Econ. Eng. Agric. Rural. Dev. 2016, 16, 331-334.

90. Köhler, M. Long-term vegetation research on two extensive green roofs in Berlin. Urban. Habitats 2006, 4, 3-26.

91. Styles, D.; Schönberger, H.; Galvez Martos, J. Best environmental management practice in the tourism sector; Publication Office of the European Union: Luxembourg, 2013. [CrossRef]

92. Valdez, M.C.; Adler, I.; Barrett, M.; Ochoa, R.; Pérez, A. The Water-Energy-Carbon Nexus: Optimising Rainwater Harvesting in Mexico City. Environ. Process. 2016, 3, 307-323. [CrossRef]

93. Paulo, P.L.; Azevedo, C.; Begosso, L.; Galbiati, A.F.; Boncz, M.A. Natural systems treating greywater and blackwater on-site: Integrating treatment, reuse and landscaping. Ecol. Eng. 2013, 50, 95-100. [CrossRef]

94. March, J.G.; Gual, M. Breakpoint Chlorination Curves of Greywater. Water Environ. Res. 2007, 79, 828-832. [CrossRef] [PubMed]

95. Chambers, B.D.; Pearce, A.R.; Edwards, M.A.; Dymond, R.L. Experiences of Green Building Professionals With Water-Related Systems. J.-Am. Water Work. Assoc. 2017, 109, 37-46. [CrossRef]

96. Algarni, S.; Saleel, C.A.; Mujeebu, M.A. Air-conditioning condensate recovery and applications-Current developments and challenges ahead. Sustain. Cities Soc. 2018, 37, 263-274. [CrossRef]

97. Matos, C.; Pereira, S.; Amorim, E.V.; Bentes, I.; Briga-Sá, A. Wastewater and greywater reuse on irrigation in centralized and decentralized systems-An integrated approach on water quality, energy consumption and $\mathrm{CO}_{2}$ emissions. Sci. Total Environ. 2014, 493, 463-471. [CrossRef] [PubMed]

98. Yüksek, I.; Karadayi, T.T. Energy-efficient building design in the context of building life cycle. In Energy Efficient Buildings; IntechOpen: London, UK, 2017; pp. 93-123.

99. Fong, K.F.; Hanby, V.I.; Chow, T.-T. HVAC system optimization for energy management by evolutionary programming. Energy Build. 2006, 38, 220-231. [CrossRef]

100. Trcka, M.; Hensen, J. HVAC system simulation: Overview, issues and some solutions. In Proceedings of the 23rd IIR International Congress of Refrigeration, Prague, Czech Republic, 21-26 August 2011.

101. DOE, U. An Assessment of Energy Technologies and Research Opportunities; United States Department of Energy: Washington, DC, USA, 2015.

102. Johnson, M.; Harfoot, M.; Musser, C.; Wiley, T. Cap and Share. Phase 1: Policy Options for Reducing Greenhouse Gas Emissions; AEA Energy and Environment: Didcot, UK, 2008.

103. Li, J.; Colombier, M. Managing carbon emissions in China through building energy efficiency. J. Environ. Manag. 2009, 90, 2436-2447. [CrossRef]

104. Harvey, L.D. A Handbook on Low-Energy Buildings and District-Energy Systems: Fundamentals, Techniques and Examples; Earthscan: London, United Kingdom; Sterling, VA, USA, 2012.

105. Liu, F. Economic Analysis of Residential Building Energy-Efficient Design Standards in Northern China: A Case Study of Tianjin City; World Bank: Washington, DC, USA, 2006.

106. Heffernan, E.; Pan, W.; Liang, X.; De Wilde, P. Zero carbon homes: Perceptions from the UK construction industry. Energy Policy 2015, 79, 23-36. [CrossRef]

107. Zuo, J.; Read, B.; Pullen, S.; Shi, Q. Achieving carbon neutrality in commercial building developments-Perceptions of the construction industry. Habitat Int. 2012, 36, 278-286. [CrossRef] 